and that the tests are unscientific. for the reason, if we unlerstand him correctly, that so many bacteria wert introduced that the antiseptic solution was exhaustel. But this position bardly seems tenable in view of the fact that control experiments showed that some of the antiseptics acting alone were perfectly efficient. As a matter of fact, we believe that any competent bacteriolngist wonld admit that the methods of Verhoeff and Fllis are gool and that the contitions miler which their tests were made are clearly stated. The assertion that the expcriments were "wholly unfair to the antiseptic and not at all comparable to any method that would be used in the practice of medicine," seems to miss or to aroid the whole point of the article in question and, indecd, that of all exprerimental work.

We believe also that too much importance fhoul mot be attached to the kind of inference that, in the opinion of the general manager of larke, Bavis \& Co., "any average r"ater of the article would draw." On examining the wording of the article with some care we are unable to discover any warrant for any reader assuming that lysol and trikresol "will not do in two hours what mercuric chlorid or carbolic acid will in one minute." In regard to acetozone, furthermore, it does not assist the average reader to an understanding of seientific data to have the general manager postulate that a conflict of authority exists between experimenters working under quite different conditions. Such imaginary inferences of imaginary readers are well known rhetorical devices; we can hardly be askel to mistake them for arguments or for statements of fact.

What, after all, is the real point of the paper by Verhoeff and Filis? Simply this: It emphasizes the restriaining or inactivating influence of albuminous matter on antiseptic substances. There is nothing wholly new in this. It has long been matter of common knowledge that some substances that are powerfully germicidal for bacteria suspended in aqueous solution are, as liosenau ("Disinfection and Disinfectants," p. 148) says of bichlorid of mercury, "totally inapplicable to the disinfection of albuminous matter." The article in ques tion, however, does call attention in a practical way and by simple and well chosen experiments to the fact that destruc tion of bacteria by chemical antisepties within the tissues, and probably also within the intestine, is not likely to occur; that, in fact, serum renders all antiseptics practically useless. So far as the imitation of natural conditions is concerned, we have only to ask whether physicians and surgeons employ antiseptic substances, as a rule, in the presence or absence of albuminous substances. If an antiseptic be used strong enough to destroy bacteria, then the tissue cells themselves will almost certainly be injured. Our knowledge of the properties of living matter in general is quite in accord with the opinion expressed by Verhoeff and Ellis that the reason why any given antiseptic is "non-irritating" is that its action is interfered with by the tissue fluids and, therefore, it is inert for bacteria and tissue cells alike. It does not necessarily follow that every albuminous substance will interfere with the action of antiseptics in the same way and to the same derree as blood serum, nor do we understand the authors of the paper under discussion to claim that this would be so. But there is no escape from the conclusion that they have slown with great clearness that there are substances present in the body fluids that prevent antiseptics from being effective within the tissues, however useful the latter may be as surface disinfectants.

One word more. may be added. The assumption by some nianufacturers of drugs and antiseptics that physicians are unwilling or incompetent to weigh evi.:ence and that they will acrept without scrutiny or question whatever general managers choose to state. is, we believe, not warranted. Specifically, in this case of antiseptic action, what ground have we, or has any one outside of the restel interests, for maintaining that non-irritating chemical antiseptics will kill bacteria within the tissues of the human body, when all the facts of observation and experiment are against this view? Is there really any good reason why we should extend to the "germi"ilal discs" of Parke, Davis \& Co., a consideration not afforded to mereuric chlorid or other well known and commercially, relatwely unprofitable, chemicals?-En.]

\section{Exploraticn of Both Kidneys Before Nephrectomy Through a Double Lumbar Incision-Question of Priority.}

Copexifagex, July 12, 1907.

To the Liditor:--1n a paper entitled "Exploration and Decapsulation of the Other Kidney Before Completing a Nephrectomy" and published in TiE Jockxal, June 1, 1907, Dr. (ieorge M. Fdebohls describes as his own a method to expose and examine both kidneys through a double lumbar incision, which, since 1893, I have had in use and recommended in cases where it was impossible by other means to deride if a single or both kidneys were affected by a disease which required extirpation.

Dr. Edebohls now proposes "that no nephrectomy should be completed without examination and desapsulation (!) of the remaining kidney:" I do not fear that any surgeon who skilfully masters modern diagnostic methods will follow Eilebohls' ultramontane proposition and perform such a lot of superfuous lumbar incisions, and therefore, I should have remained quiet if Dr. Edebohls had not forced me to speak by the following astonishing affirmations: "This method of procedure in nephrectomy was, as above pointed out, first pricticesl anl published by me, although Rorsing (Arch. f. klin. Chir. 1904-5, lxxv, 867-895) mistakenly claims priolity in the matter more than six years after my publication. Rovsing bases his clain on an operation performed by him in 1894 .

Nor do any of Rovsing's writings between 1894 and 1904, although many of them deal with nephrectomy as such and de. tail cases of nephrectomy at great length, contain any mention whatsoever of the procedure under discussion:"

All these affirmations are wrong. I have nerer "elaimed priority," simply because noboly formerly, so far as I know, had expressed a doubt thereon, before Dr. Edebohls--mistalenly-claimed the priority for himself. As Dr. Edebohts declares limself that he first practiced the method in 1894 , but first pullished the same in 1898, the following facts will very easily make his mistake evident:

My first operation was performed June 26, 1893, on a 50year-old man, who suffered from sarcoma of the left kidney, and who is still living, 14 years after the nephrectomy. This case was published and the method very minutely clescribed, discussed and recommended for certain difficult cases in my paper, "Diagnosis and Treatment of Malignant Tumors oi the Kidney," which appeared in Hospitalstidende May 16, 1894, and in Archiv, $f$. likin. Chir., 1895, xlix, pp. 406-450. Between 1894 and 1904 I furthermore described or mentioned the method in the following works: 1895: "Surgical Diseases of the Kidney and Ureter." (Volume I of my "Treatise of the Surgical Diseases of the Urinary Organs," published in Danish.) 1897: "Report of Ten Cases of Malign Tumor in the Kidney." (Trans. of the Third Scandinavian Surgical Congress at Helsingfors, Hospitalstidende, No. 36, 189\%.) Is!18: "Mysterious Hemorrhage from a Single liilney and Its cure ly Nephrestomy." (Read at the British Medical Assosiation meeting at Edinburgh; published in British Medical .Foural.) Thorkmo Rorsirg, ii.D.

Professor of Clinieal Surgery at the University in Copenhagen.

Loss of Hair After Radiotherapy.-Hallopeau (Bull. de Derm. it de syph.), that a child was cured of ringworm by Roentgen treatment, but that the exposed parts of the skull have assumed a cicatricial appearance with entire loss of hair. Balzer has observed a similar ease in a man given Roentgen treatment for an affection of the beard. After a month of severe Roentgen dermatitis the lesions healed, but left a bald patch of pigmented scar tissue. 